\title{
Rare Hemoglobin Variant Hb Yaizu Observed in Turkey
}

\author{
Erol Ömer Atalay ${ }^{a}$ Ayfer Atalay $^{a}$ Hasan Koyuncu $^{b}$ Onur Öztürk ${ }^{a}$ \\ Aylin Köseler $^{\mathrm{a}}$ Anzel Özkan ${ }^{\mathrm{a}}$ Sanem Demirtepe ${ }^{\mathrm{a}}$ \\ a Department of Biophysics, Faculty of Medicine, Pamukkale University, and ${ }^{b}$ Center for Hemoglobinopathy, \\ Ministry of Health, Denizli, Turkey
}

\author{
Key Words \\ Hemoglobin Yaizu • Abnormal hemoglobin - Laboratory \\ diagnosis · High performance liquid chromatography • \\ Premarital screening
}

\begin{abstract}
Objective: To determine the characteristic features of the rare hemoglobin $(\mathrm{Hb})$ variant $\mathrm{Hb}$ Yaizu to enable laboratory diagnosis of the hemoglobin variants during screening programs. Materials and Methods: Genomic DNA was obtained from the 4 members of a family living in Denizli province, an Aegean region of Turkey. Blood cell counts, hemoglobin composition, hemoglobin electrophoresis (both alkaline and acid), HPLC analysis, DNA sequencing and beta globin gene cluster haplotypes were done. Results: Hb Yaizu carriers were apparently healthy individuals. $\mathrm{Hb}$ Yaizu was slightly faster than $\mathrm{Hb} \mathrm{S}$ at alkaline $\mathrm{pH}$, but slower than $\mathrm{Hb} \mathrm{S}$ at acidic $\mathrm{pH}$ in hemoglobin electrophoresis. An abnormal hemoglobin peak was observed with a retention time of 4.77 min in HPLC analysis attributed to Hb Yaizu. Two members of the family were heterozygous Hb Yaizu [beta 79(EF3) Asp $>$ Asn] confirmed by DNA sequencing. The mutation was found to be linked with the Mediterranean haplotype I [+----++]. Conclusion: We have presented the details of $\mathrm{Hb}$ Yaizu, a rare hemoglobin variant that may be important to hemoglobinopathy screening programs, although its clinical significance is unclear.

Copyright $\odot 2008$ S. Karger AG, Basel
\end{abstract}

\section{Introduction}

Hb Yaizu [beta 79(EF3) Asp $>$ Asn] is a hemoglobin $(\mathrm{Hb})$ variant that has been reported in an apparently healthy Japanese woman [1]. This hemoglobin variant was identified by protein chemistry and DNA sequence analysis. Isoelectric focusing electrophoresis showed that $\mathrm{Hb}$ Yaizu is slow-moving compared to $\mathrm{Hb} \mathrm{A}$. However its detailed characteristic features are not yet known. We describe the molecular, genetic and hematological characteristics of $\mathrm{Hb}$ Yaizu in a Turkish family observed during premarital screening.

\section{Subjects and Methods}

Four members of the family were included: proposita, sister, brother and mother. Blood samples were collected in EDTA vacutainers at Denizli Hemoglobinopathy Center, Ministry of Health. Written informed consent was obtained. Blood cell counts were done with a Beckman Coulter AcT10 instrument. High performance liquid chromatography (HPLC) was performed with the BioRad Variant II system for the chromatographic identification of the abnormal hemoglobins in the hemolysates of the patient's blood prepared according to the manufacturer's directions. DNA was isolated from the individuals by standard phenol-chloroform extraction method. Hemoglobin electrophoresis (alkaline and acid) and DNA sequencing were done as previously reported [2, 3]. $\mathrm{Hb} \mathrm{A}_{2}$ and $\mathrm{Hb} \mathrm{X}$ (Hb Yaizu) quantifications were done by $\mathrm{DE}-$ 52 microcolumn chromatography [4]. Beta globin gene cluster haplotype analyses were performed as previously reported [5].

\section{KARGER}

Fax +41613061234

E-Mail karger@karger.ch

www.karger.com
(C) 2008 S. Karger AG, Basel

1011-7571/08/0174-0321\$24.50/0

Accessible online at:

www.karger.com/mpp
Prof. Dr. Erol Ömer Atalay

Department of Biophysics, Faculty of Medicine

Pamukkale University, Kinikli

TR-20200 Denizli (Turkey)

Tel./Fax +90 258211 9027, E-Mail eatalay@pau.edu.tr 

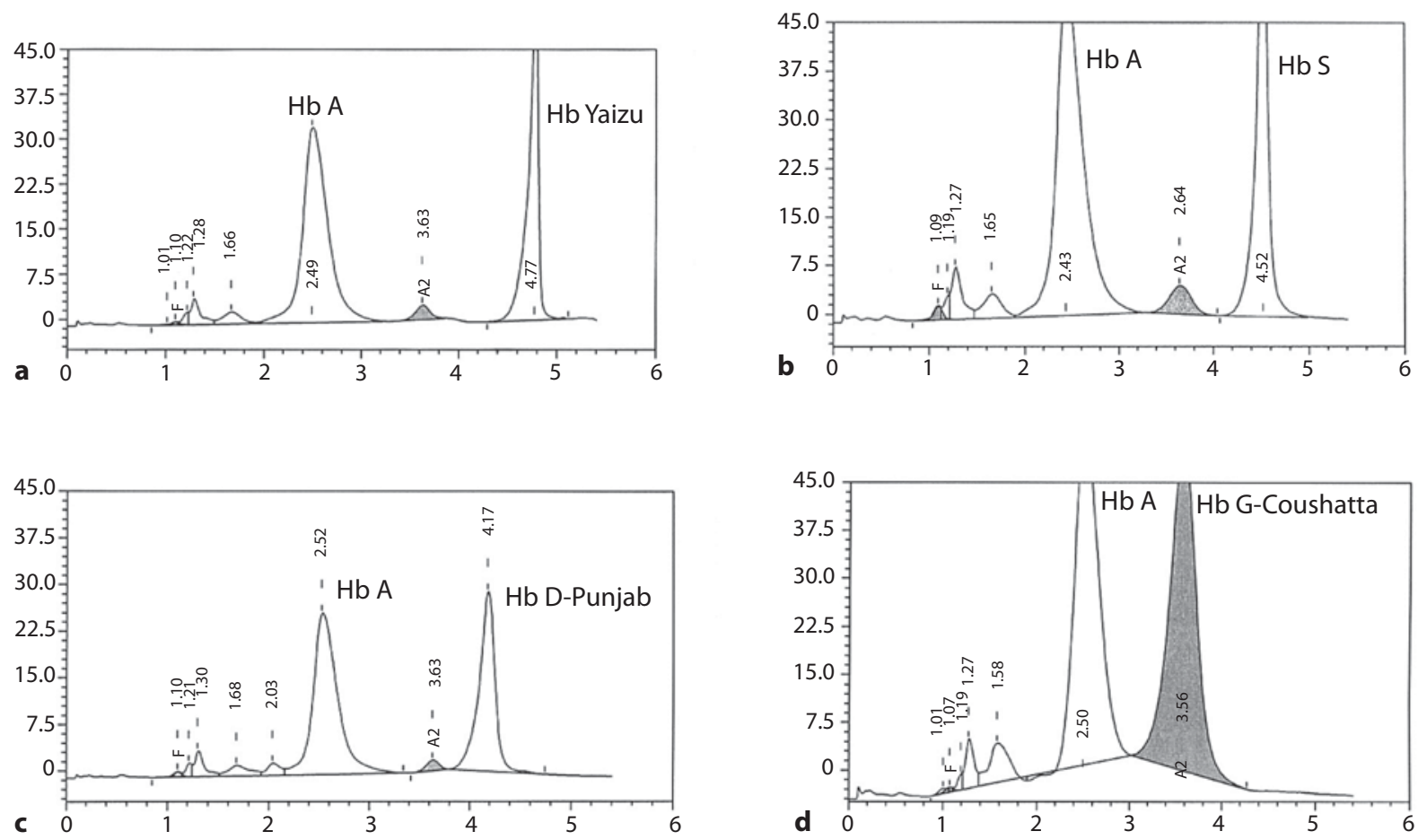

Fig. 1. Comparison of the HPLC profiles of $\mathrm{Hb}$ Yaizu and other abnormal hemoglobins. a $\mathrm{Hb} \mathrm{A} / \mathrm{Hb} \mathrm{Yaizu}$. b $\mathrm{Hb} \mathrm{A} / \mathrm{Hb} \mathrm{S}$. c $\mathrm{Hb} \mathrm{A} / \mathrm{Hb}$ D-Punjab. d Hb A/Hb G-Coushatta.

Table 1. Hematological data and hemoglobin composition of the $\mathrm{Hb}$ Yaizu carriers

\begin{tabular}{lll}
\hline & Proposita & Sister \\
\hline Age/sex & 22/F & $11 / \mathrm{F}$ \\
Hb type & A/Yaizu & A/Yaizu \\
RBC, $\times 10^{12} / 1$ & 5.21 & 5.01 \\
Hb, g/dl & 15.3 & 13.9 \\
Hct, \% & 45.6 & 42.4 \\
MCV, fl & 87.0 & 85.0 \\
MCH, pg & 29.3 & 27.7 \\
MCHC, g/dl & 33.6 & 32.7 \\
RDW, \% & 12.7 & 13.0 \\
Hb A,$\%$ & 2.6 & 2.9 \\
Hb Yaizu, \% & 40.5 & 37.6 \\
\hline
\end{tabular}

\section{Results}

Hematological data and hemoglobin composition of the $\mathrm{Hb}$ Yaizu carriers are given in table 1. The HPLC result of $\mathrm{Hb}$ Yaizu is shown in figure 1. The proposita and her sister carry an abnormal hemoglobin peak with retention time of $4.77 \mathrm{~min}$ (fig. 1a). The HPLC profiles of $\mathrm{Hb}$ S, Hb D-Punjab (Los Angeles) and Hb G-Coushatta are also shown for comparison in figure 1 . The retention times are 4.52, 4.17, and 3.56 min for the $\mathrm{Hb} \mathrm{S}, \mathrm{Hb}$ D-Punjab and Hb G-Coushatta, respectively. Hemoglobin electrophoresis done at alkaline and acidic $\mathrm{pH}$ values is shown in figure $2 . \mathrm{Hb} \mathrm{X}$ is slightly faster than $\mathrm{Hb} \mathrm{S}$ at alkaline $\mathrm{pH}$, and slower than $\mathrm{Hb} \mathrm{S}$ at acidic $\mathrm{pH}$. DE-52 microcolumn chromatography shows that the elution for $\mathrm{Hb} \mathrm{X}$ is slightly slower than that for $\mathrm{Hb} \mathrm{S}$ with developer A-200, the same developer used also for $\mathrm{Hb}$ S (0.2 M glycine/0.003 M KCN/0.2 M NaCl). Nonradioactive DNA se- 


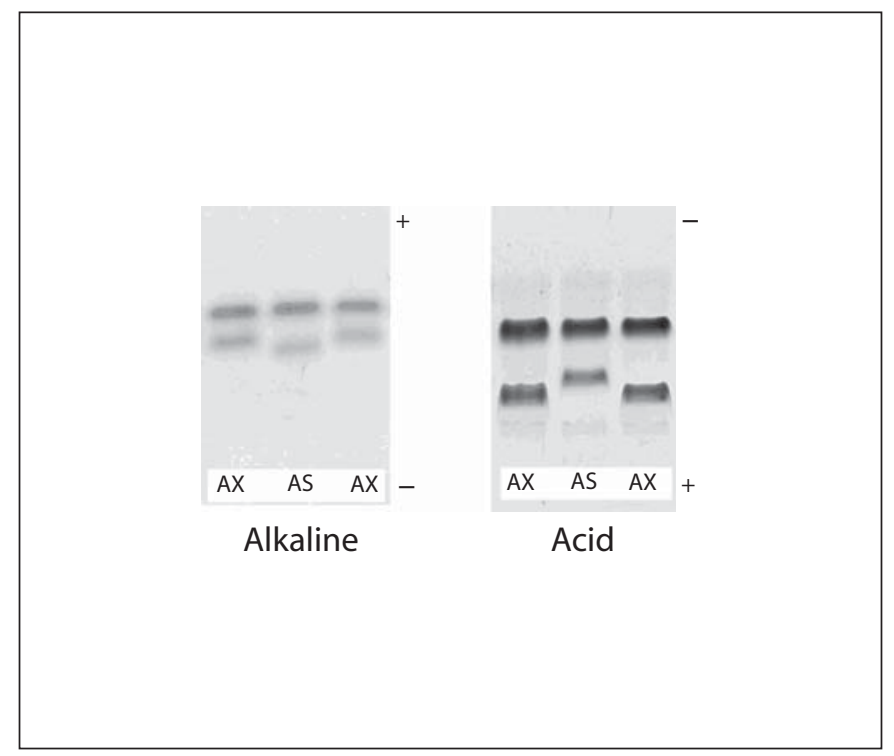

Fig. 2. Hemoglobin electrophoresis of the Hb Yaizu in acid and alkaline $\mathrm{pH}$.

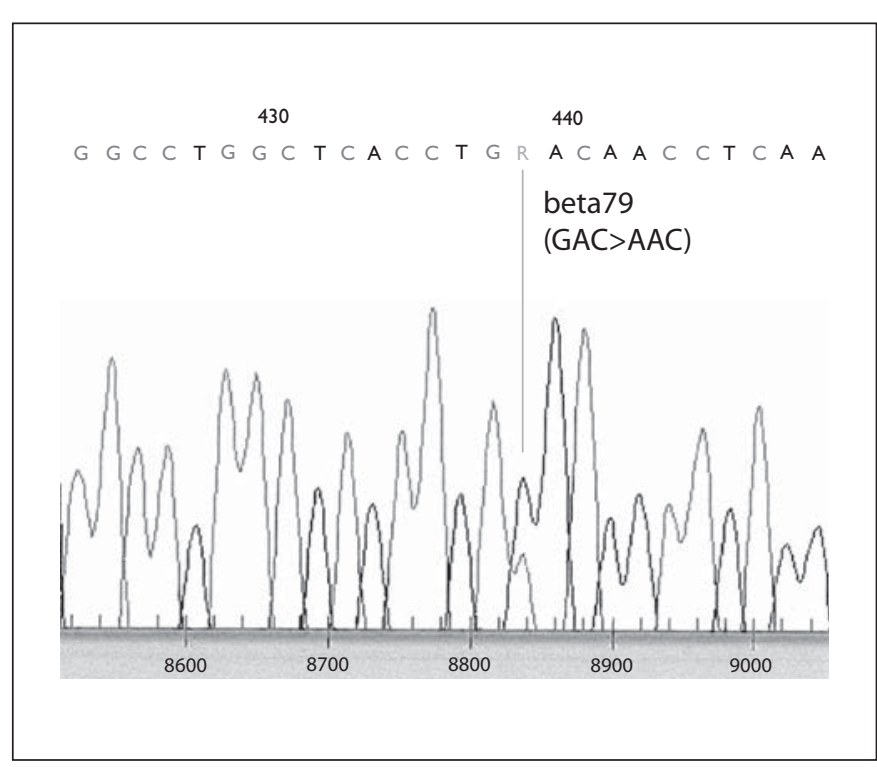

Fig. 3. DNA sequencing of $\mathrm{Hb}$ Yaizu (beta 79, GAC $>A A C$ ).

Table 2. Beta globin gene cluster haplotypes of $\mathrm{Hb}$ Yaizu

\begin{tabular}{|c|c|c|c|c|c|c|c|c|}
\hline & Hemoglobin & $\begin{array}{l}5^{\prime}-\varepsilon \\
\text { HincII }\end{array}$ & $\begin{array}{l}\mathrm{G} \gamma \\
\text { HindIII }\end{array}$ & $\begin{array}{l}\text { A } \gamma \\
\text { HindIII }\end{array}$ & $\begin{array}{l}5^{\prime}-\psi \beta \\
\text { HincII }\end{array}$ & $\begin{array}{l}3^{\prime}-\psi \beta \\
\text { HincII }\end{array}$ & $\begin{array}{l}5^{\prime}-\beta \\
\text { AvaII }\end{array}$ & $\begin{array}{l}3^{\prime}-\beta \\
\text { HinfI }\end{array}$ \\
\hline Proposita & $\mathrm{Hb}$ A/Hb Yaizu & $+1-$ & $+1-$ & $-1-$ & $+/-$ & $+1-$ & $+/+$ & $+/+$ \\
\hline Mother & $\mathrm{Hb} \mathrm{A} / \mathrm{Hb} \mathrm{A}$ & $+/-$ & $-1-$ & $-1-$ & $-1-$ & $-1-$ & $+/+$ & $+1-$ \\
\hline Sister & $\mathrm{Hb}$ A/Hb Yaizu & $+/+$ & $-1-$ & $-1-$ & $-1-$ & $-1-$ & $+/+$ & $+/+$ \\
\hline Brother & $\mathrm{Hb} \mathrm{A} / \mathrm{Hb} \mathrm{A}$ & $+1-$ & $+1-$ & $-1-$ & $+/-$ & $+1-$ & $+/+$ & $+1-$ \\
\hline
\end{tabular}

quencing shows that the mutation at beta globin gene codon 79 (GAC>AAC) causes the abnormal Hb X (fig. 3). The beta globin gene cluster haplotype of Hb Yaizu is given in table 2. Beta globin gene cluster haplotypes of the family members show that the Hb Yaizu [beta 79(EF3) GAC $>A A C]$ mutation is linked with the Mediterranean haplotype I [+----++].

\section{Discussion}

Hb Yaizu [beta 79(EF3) Asp >Asn] has been reported only once previously [1]. Heterozygotes are apparently healthy and their hematological data are within the normal range. In the present report, $\mathrm{Hb}$ Yaizu was identified by protein chemistry and DNA sequence analysis, which confirmed the G-to-A mutation in codon 79. Isoelectric focusing shows that it is slow-moving compared to $\mathrm{Hb} \mathrm{A}$. Its HPLC profile is near the $S$ window with a $4.77-\mathrm{min}$ retention time on the Biorad Variant II system (fig. 1). The chromatographic pattern of $\mathrm{Hb}$ Yaizu is similar on both HPLC and DE-52 microcolumn, being slower than $\mathrm{Hb} \mathrm{S}$ profiles due to the side chain of the asparagine residue at beta 79(EF3) exhibiting high affinity into the column matrix. Its beta globin gene cluster haplotype is reported here for the first time and it indicates a Mediterranean genetic origin. Since the beta globin gene cluster haplotype of the Japanese case was not determined, it is not possible to say that it shares the same genetic origin with the Turkish case. 


\section{Conclusion}

We have presented the details of $\mathrm{Hb}$ Yaizu, a rare hemoglobin variant that may be important to hemoglobinopathy screening programs, although its clinical significance is unclear.

\section{Acknowledgments}

This work was supported by the Pamukkale University Research Fund Projects No. 2005SBE001 and 2005SBE002.

\section{References}

1 Harano T, Harano K, Katsuki T: Hb Yaizu [beta 79(EF3)Asp>Asn]: a new beta chain variant found in a Japanese female. Hemoglobin 1995;19:21-25.

2 Atalay EÖ, Koyuncu H, Turgut B, Atalay A, Yildız S, Bahadır A, Köseler A: High incidence of Hb D-Los Angeles [ $\beta 121(G H 4) G l u-$ Gln] in Denizli Province, Aegean region of Turkey. Hemoglobin 2005;29:307-310.

$\checkmark 3$ Köseler A, Atalay A, Koyuncu H, Turgut B, Bahadir A, Atalay EO: Molecular identification of a rare hemoglobin variant, $\mathrm{Hb}$ J-Iran [beta77(EF1)His $>$ Asp], in Denizli province of Turkey. Turk J Haematol 2006;23:164-166.
4 Efremov GD: Quantitation of hemoglobins by microchromatography; in Huisman THJ (ed): The Hemoglobinopathies. Edinburgh, Churchill Livingstone, 1986, pp 72-90.

5 Falchi A, Giovanni L, Vacca L, Latini V, Vona G, Varesi L: $\beta$-Globin gene cluster haplotypes associated with $\beta$-thalassemia on Corsica Island. Am J Hematol 2005;78:27-32. 